Carlo Grevy*

\title{
Metaforer, scenarier og teknologi ${ }^{1}$
}

\section{Introduktion}

I min afhandling har jeg beskæftiget mig med metaforer, og hvordan de fungerer i fagsprog. Undersøgelsen omfatter $10 \mathrm{pc}$-magasiner, hvor der er fundet ca. 6000 metaforer. Jeg skal her først redegøre for baggrunden for mit projekt - dernæst redegøre for resultaterne af undersøgelsen og nogle af dens teoretiske konsekvenser.

Men hvad er metaforer, og hvorfor er de interessante at beskæftige sig med? Gennem årtusinder har forskere givet forskellige typiske eksempler på metaforer. Således er ytringer som Peter er en raev og Akilles er en løve metaforer. I metaforerne taler man om et emne, men man taler om det på en mere eller mindre umulig måde - for hvordan kan man fx tale om en person og sige, at han er et dyr, som i de to eksempler? Hvordan kan vi forstå sådanne metaforer? Sådanne spørgsmål er der blevet brugt mange forskningsressourcer på at besvare - og situationen er i dag langtfra afklaret.

Aristoteles var en af de første, der blev opmærksom på fænomenet og siden har næsten utallige fulgt hans eksempel og taget dette emne metaforerne - op. Følger vi de europæiske ideers historie, ser vi en skiftende interesse for emnet op til nutiden. Det er især interessant at betragte interessen for metaforer i det 20. århundrede, hvor forskningen inden for dette felt stiger meget kraftigt. Mange har iagttaget dette fænomen, dette

1 Denne artikel er en let omskrevet version af forsvaret af min ph.d.-afhandling Metaforer, scenarier og teknologi. En undersøgelse af computermetaforer på et empirisk konstruktivistisk grundlag, den 5. april 2002 på Handelshøjskolen i Århus. Til afhandlingen hører bilag, som der henvises til i artiklen.

* Carlo Grevy

Center for Leksikografi

Handelshфjskolen $i$ Arhus

Fuglesangs Allé 4

DK-8210 Århus V 
at interessen for metaforerne stiger. Fx nævnte Wayne Booth i 1978 på en konference, at hvis antallet af forskere, der beskæftiger sig med metaforer, ville tiltage i samme takt fremover, som det var sket de sidste par år, ville der i år 2039 være flere metaforforskere, end der var mennesker i verden. Metaforerne bliver således i det 20. århundrede meget synlige og væsentlige - og de bliver set som sprogets omnipotente princip.

\section{Den kognitive tradition}

Tidligere mente man, at metaforer var noget, der især blev anvendt i litteratur og poesi. Men man er nu blevet opmærksomme på, at metaforer bruges inden for alle mulige andre sammenhænge. I det 20. århundrede er det derfor ikke kun litterater, der har metaforerne inden for deres synsfelt - en hel hær af forskere, der kommer fra områder som pædagogik, psykologi, filosofi, naturvidenskab og socialvidenskab, kaster sig over emnet. Især de to forskere Lakoff og Johnson - der er henholdsvis lingvist og filosof - gør sig bemærkede, idet de forsøger at systematisere de metaforer, som vi anvender i dagligdagen. Herved får de også alle gjort opmærksomme på, at der findes en lang række væsentlige metaforer uden for det litterære område. Lakoff og Johnson skelner ikke mellem døde og levende metaforer, som man gør inden for de litterære discipliner. Nej, de gør opmærksom på, at ganske almindelige ord og udtryk er metaforer, fx: at skyde sig selv i foden, flaskehalsproblemer, kфlig stemning, jeg er helt oppe at køre i dag - jeg er helt nede, det skal du få betalt, og: hun skyder med skarpt - hun skyder mine argumenter $i$ sank. Mange af deres udtryk ville man tidligere slet ikke betragte som metaforer - man ville sige, at de var døde - men Lakoff og Johnson hævder og demonstrerer deres ide om, at sådanne metaforer hænger sammen i systemer begrebsmetaforer om man vil - således at vi fx kan sige, at vi har argumenter er krig eller viden er mad. Vi taler ifølge Lakoff og Johnson om krig, som var det argumenter, når vi siger, at hun skød mine argumenter i sænk, og vi taler ifølge dem om viden som mad, når vi taler om, at en bog kan fordøjes.

Det, som Lakoff og Johnson også hævder, er, at metaforerne afspejler, hvordan vi tænker - metaforerne er kognitive redskaber. Vi tænker og indretter vores handlinger således, som de kognitive strukturer fortæller os, at vi skal gøre. Taler vi om diskussion som krig, vil vi også have en adfærd, der afspejler dette. 
Grunden til, at jeg her fremhæver Lakoff og Johnson, er ikke, at jeg mener, de har ret. Men det forholder sig sådan, at megen af den forskning, som er foregået de sidste ca. 20 år - inden for alle de nævnte forskellige videnskabelige discipliner inden for metaforområdet - uheldigvis bygger på Lakoff og Johnsons ideer.

Mange har taget deres ideer ukritisk til sig. Det er ikke så mærkeligt, at man lod sig rive med i 1980'erne, da de kom med deres ideer - for det så jo ud som om, at en række problemer mellem tænkning og sprog nu endelig var blevet løst. Og denne række problemer kunne løses mere eller mindre som skrivebordsarbejde, fordi man inden for denne forskningstradition ikke så det nødvendigt at undersøge, om det nu også forholdt sig, som man umiddelbart antog. Man kunne ud fra selvkonstruerede teksteksempler forklare, hvordan vi tænker og fungerer som mennesker.

Det, der måske kan forekomme mærkeligt, er, at der ikke er sket så meget nyt inden for metaforområdet de sidste ca. 20 år. Med Lakoff og Johnson blev der åbnet op for en ny forskningstradition, hvor man principielt kunne studere metaforer overalt - men der blev samtidig låst af for nytænkning inden for området, hvilket har betydet, at forskningen mere eller mindre er gået $\mathrm{i}$ stå. Det har vist sig vanskeligt at komme ud af en bestemt forskningstradition, hvor man kunne lave en lang række antagelser om sproget på et meget løst empirisk grundlag.

Da de to forskere præsenterede deres ideer i 1980'erne, var der dog også en række kritikere, som fremførte, at der ikke var det empiriske grundlag for de antagelser, som de hævdede. Der var også mange, der mere ukritisk roste deres initiativ. Her i Danmark har vi ligeledes kunnet finde både positive og kritiske anmeldelser af deres arbejde. På baggrund af denne kritik kunne man så forvente, at forskerne skiftede retning, blev mere opmærksomme på det spinkle empiriske arbejde, der havde fundet sted, og at der efterfølgende blev taget nye initiativer. Men principielt er der ikke sket noget nyt! Lakoff - og andre - har hårdnakket hævdet, at der var eller snart kunne skaffes belæg for deres antagelser. Det fremgår både af de ting, han har skrevet og af nogle af de foredrag, han har holdt de sidste par år. Og Lakoff - og andre - har ikke på noget tidspunkt hævdet, at et sådant belæg var uvæsentligt eller unødvendigt - snarere modsat. Man kan spørge sig selv, hvorfor forskningen så ikke har skiftet spor. 
Den har ikke skiftet spor - og det har jeg vist i afhandlingen - da den måde, som man har kritiseret den kognitive forskning på, er sket på det samme metodiske grundlag som det, man har forsøgt at kritisere. $\mathrm{Og}$ hvorfor skulle nogen så tage kritikken til efterretning? Lakoff og Johnson har fundet belæg for mange af deres antagelser ved at snakke med hinanden, ved at snakke med nogle af deres studerende og ved at slå op i ordbøger mv. De har ikke undersøgt tekster systematisk. Og de har ikke undersøgt, om disse eksempler faktisk også blev anvendt. Den forskningstradition, de arbejder inden for, kan betegnes tekstpoesi: De finder mere eller mindre selv nogle eksempler, som passer til deres antagelser. Selv de skrappeste kritikere af den kognitive semantik og dens empiriske grundlag er ikke kommet med konkrete metaforer fra egne undersøgelser, der kunne antaste Lakoff og Johnsons egne eksempler. Kritikerne har anført, at der ikke var empiriske beviser til stede - men de har holdt sig inden for den samme forskningstradition og ikke selv ved egen handling vist, at forskningen kunne foregå på en anden måde. Og ofte har de selv opstillet en række mere eller mindre selvopfundne alternativer. Og en sådan kritik maner ikke netop til besindelse og refleksion - den legitimerer blot traditionen.

I min egen unders $\emptyset$ gelse af metaforer er jeg først og fremmest interesseret $i$ at finde $u d$ af, hvilke metaforer vi bruger, og hvordan metaforerne er strukturerede. Dette er dokumenteret i bilag 1. Inden jeg gik i gang med dette arbejde, fandt jeg det dog interessant at finde ud af, hvorledes den kognitive forsknings metaforer var strukturerede. Med Internettet havde jeg adgang til et forholdsvis stort indekseret sprogligt materiale, og da jeg tjekkede frekvenserne af en række af Lakoff og Johnsons metaforiske ytringer, fandt jeg, at en del af dem var godt repræsenteret - det vil sige fra flere hundrede til flere tusinde hits. Men der var også en række, der fandtes i et meget lille omfang.

På side $108 \mathrm{i}$ afhandlingen vil man finde en række frekvenser for de første tre begrebsmetaforer, som Lakoff nævner på sin hjemmeside på Internettet. Der er søgt på forskellige kollokationer, dvs. forskellige udgaver af Lakoffs eksempel. Således er der søgt på forskellige bøjninger af substantiverne og verberne og disses kombinationer.

Af denne lille test fremgår følgende:

1. Der er nogle af Lakoffs ytringer, der næsten ikke bruges. 
2. I de tilfælde, hvor de næsten ikke bruges, findes de dog altid på hans hjemmeside (fx: explanation impenetrable - her er tre stk.).

3. Der er nogle af ytringerne, der er meget mere frekvente end andre.

4. Nogle af Lakoffs metaforer bruges i stort omfang, men i en anden form, end den som Lakoff selv giver som eksempel.

Ud fra dette ser det ikke ud til, at Lakoffs metaforer er blevet unders $\emptyset$ gt. Forudsætter vi nemlig, at der i Internettets stort sammensatte korpus på ca. otte mia. ord er en vis overensstemmelse mellem den måde, sproget bruges på - og den måde sproget i øvrigt bruges på (fx i dagligsproget) er det vanskeligt at sige, at der er tale om nogle metaforer, som vi virkelig lever med. Nogle af dem bruger vi nemlig kun meget sjældent eller aldrig. Eller også bruges de kun som eksempler på sprog. I en undersøgelse af Internettet inden for den sidste uges tid, finder vi tre steder Lakoffs eksempel "ate the lesson up". De to af dem findes på Lakoffs egen hjemmeside, og den tredje findes på min metaforhjemmeside, hvor jeg bruger metaforen én gang som eksempel på Lakoffs metaforer.

For mig at se er den metodik, der her lægges for dagen, ikke særlig frugtbar. Vi kan naturligvis anlægge det synspunkt, at den kognitive forskning arbejder med principielt skjulte strukturer, som udøver deres aktivitet under overfladen. Det kunne nemlig godt være rigtigt! Problemet ved denne strategi - at antage at utilgængelige, men virksomme, kræfter styrer vores sprog - er, at vi aldrig kommer til en afgørelse. Fordi en sådan videnskabelig strategi gør sig immun over for kritik udefra, lukker den samtidig af for nye indsigter. Den lytter ikke til empirien, for den siger altid: Det kunne være anderledes - vi kan blot ikke vide det. Set fra min synsvinkel er empiri altid et bedre argument - for det er bedre at tage fat i nogle strukturer, som vi ved faktisk bruges - end at forblive ved nogle strukturer, som aldrig kan verificeres.

Når jeg her har vist, at Lakoffs ytringer ikke anvendes i selv meget store korpora, er dette ikke en dokumentation af, at han ikke kan have ret. For vi kan ikke vide, om han har ret eller ikke. Det, som er vist, er derimod, at der ikke synes at være verificerbar empiri bag den kognitive forsknings resultater. Lakoff og Johnson skriver for nylig, at det, vi iagttager, kun udgør toppen af isbjerget - de kognitive strukturer ligger nedenunder (Lakoff og Johnson 1999). Det er mit synspunkt at vi burde bruge vores kostbare ressourcer på at undersøge det, vi kan se af isbjerget - dvs. ca. $10 \%$ ifølge Lakoff og Johnson - i stedet for at gisne om de 
$90 \%$, vi ikke har adgang til. Hvis vi koncentrerer os om det, vi kan se, kan vi få en større indsigt, end ved slet ikke at gøre forsøget, dvs. ved slet ikke at undersøge, hvorledes sproget reelt bruges.

\section{Empirisk konstruktivisme}

Valget af computerfagsprog i denne undersøgelse skyldes en forventning om, at fagsprog, der omhandler emner, der forandrer sig i særlig høj grad, har brug for metaforer. Inden for computerteknologien har man en forventning om, at hastigheden for computerens processor - for den sags skyld også dens lagerkapacitet - fordobles for hver 18. måned. Dette betyder inden for dette fagområde ikke kun en kvantitativ eksponentiel vækst, men også en kvalitativ, hvor nye produkter hele tiden udvikles.

Lad os se på, hvordan metaforer kan undersøges. I undersøgelsen af pc-magasinerne fandt jeg ret hurtigt, at man brugte en hel række ganske almindelige udtryk fra hverdagen - fra vores primære sprog - til at betegne højteknologiske produkter. Man taler om døre, låse, vinduer, porte, sokler, nфgler, postkasser osv. Der tales om at computeren kører, har høj hastighed, om at filer kan omdirigeres, om gaester på nettet osv.

I søgningen af metaforer er alt, der kunne tænkes at være metaforer, $\mathrm{i}$ første omgang blevet registreret. I første omgang har jeg ladet mig inspirere af de eksempler, metaforforskningen hidtil har givet på metaforer. Indsamlingen og systematiseringen af metaforerne er altså ikke foregået ud fra en færdig teori om metaforer, som jeg havde i forvejen. Jeg er naturligvis ikke startet på bar bund - jeg har taget udgangspunkt i de bestående forskellige teorier om metaforer - teorier, som der er redegjort for i den første del af afhandlingen. De bestående teorier (som alle hidtil altså har været etableret uden systematiske empiriske undersøgelser af væsentlig art) er således kommet på prøve. Kunne det, som man sagde fra de forskellige videnskabelige traditioner, nu også holde? Det viste sig - som tidligere nævnt - at disse teorier ikke holdt. Flere af de antagelser, man har haft om metaforer, viser sig ikke at være korrekte. Med mit arbejde kommer jeg derfor også til at pege på, hvor lidt vi egentlig ved om, hvorledes metaforer fungerer, og hvor nødvendigt det er at se på, hvorledes vi bruger sproget, før vi siger noget om, hvordan det virker.

Andre har også beskæftiget sig med computermetaforer, og her har man fx fundet motorvejsmetaforer. Deignan (1995) har udgivet en ordbog over forskellige metaforer - og nogle af disse har også kunnet findes i 
unders $\emptyset$ gelsen her. Der findes dog til dato ikke større systematiske undersøgelser af metaforers strukturer - og dette betyder, at metaforforskningen i dag ikke hviler på undersøgelser af mere end ganske få hundrede metaforer.

I min undersøgelse har jeg registreret alt, der umiddelbart kunne tages som metaforer - senere har jeg sorteret i dette materiale. I bilag 1 side 31 og frem er de ca. 6000 metaforer registreret efter deres type. Følgende oplysninger er indeholdt i databasen: Metaforfeltet (hele ytringen) - kortform - type (der registreres som en alfanumerisk kode) - kildeoplysninger (side, nr., årgang) - kildetype (dvs.: Er det en artikel eller en reklame?) - leksikaliseringsgrad (høj/lav) - fagbrug (vedrører det computerne eller helt andre ting?).

Feltet i databasen, der vedrører kortformen, er væsentlig, idet det metaforiske her i en reduceret form registreres mht. metaforernes kilde- og målområde.

Metaforerne er opdelt efter forskellige såkaldte scenarier, dvs. områder, hvor ordene hænger sammen i deres såkaldte bogstavelige betydning. Et sådan scenario udgøres af fx motorvejsmetaforerne, som vi ser på side 61 i bilag $1 \mathrm{og}$ frem. Her ser man bl.a. en række kortformer af sådanne metaforer, der vedrører computere mv.: Microsoft stikker en kap i hjulet, cd-rommen lå og fedtede rundt, det har varet et problem at bremse, pramier står $i k \phi-$ og fortsætter vi fremad, ser vi en hel række af sådanne metaforer: Pc'en er langsom, en fartdjavel, edb-kortet har fået fat i stcengerne, produktet stormer frem, kortet lå pant med en højere hastighed, computeren har lyntogsfart. De her nævnte metaforer vedrører computerens hastighed mv. - men man kan også navigere rundt i det elektroniske landskab som et skib på vandet (side $67 \mathrm{og}$ frem i bilag 1): Navigation på nettet, der er en flåde af pc'er, en printer er et flagskib, en plan er kuldsejlet, der er et hav af editorer og informationsfloder, der er sat nye fabrikker i sфen, der er batterihavari, en edb-virksomhed kan vare på rette kurs, der anvendes ankre i et program, en model kan holde vand, en disk falder agterud, etc.

At arbejde med computere bliver at k $\phi$ re computere (fx bilag 1, side 80 og frem): Der er programk $\phi r s l e r$, computerne $k \phi r e r$, RAMDAC $k \phi r e r$ med $h \phi j$ hastighed, man kan teste den pc, man overvejer at køre, man

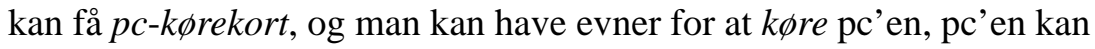

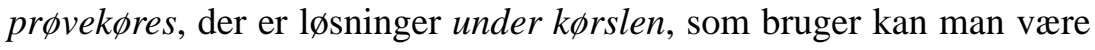




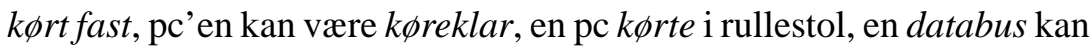

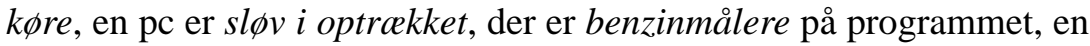
pc er en sejtrakker eller kan skrottes. Det fortsætter fx på side 91 i bilag 1: Der er trafik på nettet, data er undervejs og følger den nemme vej eller rute, program fфrer os ned ad vejen, teknologi finder vej, vejen er banet - og der kan være omveje, der er teknologiskift, filer omdirigeres, tager kovendinger, accelererer eller bliver bremset. Der kan være genveje man kan overhale vennerne på Internettet, pc-branchen kan overhales indenom, man kan foretage online-rejser, tage sin rejsetaske med, få isdnadgang (når man er rejst længe og er kommet frem til målet) - og man kan besфge nettet (side 108 ff.).

Dette var eksempler på, hvorledes metaforer fungerer integrerede: De hænger sammen i kildeområder og bruges til at sige noget om et nyt teknologisk område. Vi siger ikke noget om, hvorledes computeren fungerer, når den kфrer, accelererer eller anvender genveje. Vi bruger derimod nogle almindelige ord fra hverdagen til at sige noget om et område, vi dybest set ikke ved ret meget om. Men ordene og udtrykkene er med til at hjælpe os til at tale om det - og vi taler om det på en sammenhængende måde. Alle de nævnte ord og udtryk vedrørende kørsel eller navigation på havet hænger sammen for os, fordi vi har nogle primære erfaringer i vores liv, hvor vi bl.a. kan køre og sejle. Læg også mærke til detaljeringsgraden i ordene og udtrykkene. Vi siger ikke bare, at computerne kører nej denne kørsel nuanceres, så vi både kan tale om at en pc er køreklar, kan overhale og at vi selv skal have $p c$-kфrekort. Det, at vi benytter os af utallige af sådanne variationer i metaforerne, gør, at vi kan få det, som vi taler om, til at fremstå som et sammenhængende konsistent område. Metaforer skaber sammenhæng.

De nævnte bevægelsesmetaforer udgør dog kun en lille del af alle de erfaringsområder fra hverdagen, som vi kan tage $\mathrm{i}$ anvendelse, når vi skal tale om ny computerteknologi.

På side 172 i afhandlingen har jeg opstillet en oversigt over samtlige metaforiske områder. Det vil sige, at der her er tale om et samlet system over de metaforer, som vi har til rådighed, når vi skal tale om et emne. Bilag 1 udgør baggrundsmaterialet for denne oversigt. I oversigten finder vi under det ikke-menneskelige område kendte metaforiske kildeområder, som vi ser i tingsliggørelser, botaniseringer og animeringer. Et program 
kan fx være en lysende perle, sidste skud på stammen, eller have en levetid. Dette er forholdsvis simple metaforer.

Menneskelige aktiviteter og rum udgør en stor del af metaforerne. Disse er delt op i menneskelige aktiviteter, sociale rum, overlevelsesrum/ produktion, rum uden for produktion, kunst og kultur, sociale rum uden for kontrol mv. Fx er metaforer, der vedrører kriminalitet, krig, sygdom og religiøsitet sådanne metaforer. Når der tales om rum for produktion, henvises der til de forskellige historiske produktionsformer - fx når der inddrages kildeområder fra jagt- og fiskeribaserede samfund eller fra

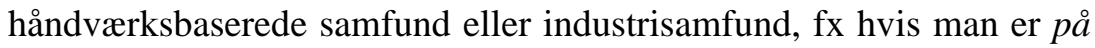
jagt efter en pc, gennemtrawler nettet - eller hvis man taler om computeren som en maskine, der kan justeres, bygges, tunes, neddrosles, gå som smurt, være et kraftvark og fx være helstфbt (jf. bilag 1 side 333). Disse produktionsområder har ikke tidligere været betragtet som kilder $\mathrm{i}$ metaforerne - men fordi de fungerer på en sammenhængende måde, er der den samme begrundelse for at betragte dem som metaforer. At man ikke tidligere har fundet sådanne ret udbredte metafortyper, kan kun skyldes, at man ikke har lavet systematiske undersøgelser af sprogbrug.

Der er flere vigtige ting - og også teoretisk helt nye ting - som karakteriserer dette system: Det er et lukket system, der indeholder overskrifterne på samtlige aktuelle kildeområder i metaforerne - men det indeholder bestemt ikke alt, for alt er ikke metaforer. Det indeholder derimod en række meget konkrete områder af ord og udtryk, som konkret kan findes i bilag 1 . Når det er et lukket system, betyder det også, at vi i praksis kun bruger disse kildeområder i metaforisk sprog. Vi laver altså ikke hele tiden nye kreative metaforer eller alle mulige krydsninger. Vi bruger hele tiden nogle bestemte. Metaforerne er altså ikke så specielt kreative, som forskningen hidtil har hævdet. Og det er måske ikke så mærkeligt. Kildeområderne skal jo netop være stabile for at fastholde alle de ting, som forandrer sig i verden: Den teknologiske udvikling, de nye produkter og de nye sociale relationer, som denne teknologi medfører. Metaforerne gør, at vi kan tale sammen om ting i hurtig forandring på en sammenhængende måde.

Som punkt tre i opstillingen er der metaforer, der tager udgangspunkt i orientering og bevægelse - og dette sker i forskellige fysiske og kulturelle rum. Fx hører motorvejsmetaforerne til her. Et metaforområde, som jeg vil fremhæve, er også de menneskelige aktiviteter. Der er de såkaldte 
ydre aktiviteter, altså aktiviteter, som mennesker kan foretage sig, fordi de har en krop. Disse aktiviteter bruges som kildeområde i metaforerne (bilag 1, side 206 og frem): Data kan ikke holde sig i ro, sites vil ikke stå tilbage for andre, Lotus barsler med program, links peger, skarm begynder at røre på sig - osv.

De indre aktiviteter er dog vigtigere: Programmer kan introducere, udstråle arrogance, varetage styring, vente på deres tur, vare hammede, få ny identitet, få at vide at noget sker, erkende en situation, have håb, fors $\phi$ ge noget, advare om fejl, signalere et $\phi$ nske, foregive at vare del af et netvark, give definitioner, opdage enheder, krave, fremme uvasen, stille krav, hoevde, gфre sit bedste - ja listen er meget lang. Der henvises til en lang række evner og kvaliteter, som kun mennesker ellers har: Programmer er intelligente eller dumme, husker, vågner, siger noget, stiller spфrgsmål, foreslår, taler, giver råd, svarer, фnsker, beder om, fortcller, fremturer, kommanderer, antyder, erklaerer, påstår, benytter sprog, dikterer, laser, er stressede, holder фje med, leder i sin liste, lytter, føler, tonker, forstår, udnytter, skifter strategi, kraver, sørger for, tillader, valger, barer skylden, hjalper, unders $\phi g e r$, blander sig. I oversigten i bilag 1 side 2728 fremgår det, at der er knapt et tusinde metaforer af denne type, hvor det komplekse menneskelige område bruges til at sige noget om computerteknologien.

Hvor nuanceret denne menneskeliggørelse er, får man bedst et indtryk af ved selv at gennemgå noget af materialet - men der er tale om, at menneskeliggørelser af denne art, hvor programmer og computere beskrives via sådanne termer, er meget udbredte. Når der bruges termer fra det menneskelige område, er der tale om, at ord og udtryk fra et særdeles komplekst område - nemlig noget, der vedrører menneskelige evner bruges til at sige noget om teknologi.

Den måde, som man hidtil har opfattet metaforer på, er, at man har ment, at metaforer gør tingene mere konkrete. Når man fx taler om et abstrakt begreb som tid, som om det var et rum, er der tale om en sådan konkretisering: Man kan se bagud i livet - og se frem osv. I teorierne om metaforerne har man ment, at konkretiseringer fik os til at forstå: Dette fremgår - som jeg har vist - når man kigger efter i samtlige væsentlige danske sproghåndbøger og encyklopædier og leksika. Men som det er demonstreret her, er det meget udbredt at bruge et komplekst område til at sige noget om et andet område. Metaforernes hovedfunktion er nemlig 
ikke, at vi bedre skal kunne forstå noget - metaforernes hovedfunktion er, at vi skal kunne finde sammenhængende ord og udtryk i et område til at sige noget om forhold i et andet. Det, der er afgørende for, om vi anvender det ene eller det andet kildeområde, er, om den sproglige kompleksitet er til stede for at kunne sige tilstrækkelig mange forskellige ting om målområdet. Skal vi tale om noget komplekst, må vi vælge et komplekst kildeområde - skal vi tale om noget mere simpelt, kan vi anvende et mere simpelt område (hvor vi har færre sproglige nuancer), fx dyre- eller planteriget. Men om vi bruger det ene eller det andet område, har ikke noget at gøre med, om vi bedre forstår det, vi taler om.

\section{Konklusion}

I denne undersøgelse er der valgt en metodik, der er anderledes end traditionens. Her er der blevet foretaget systematiske empiriske undersøgelser. Metodikken er anderledes end den, som man ser anvendt i den kognitive semantik - den er en kritik af den bestående forskning - og det er en anden metodik end den, der hidtil er benyttet til at kritisere fx Lakoff og Johnson. Projektet her har givet nogle andre resultater:

1. Metaforer findes i et færdigt sammenhængende system.

2. Metaforernes funktioner er ikke at gøre konkret, men at muliggøre, at et vidensområde kan bruges på et andet - uanset kompleksitet.

3. Metaforerne er ikke specielt kreative.

4. Især i fagsprog må metaforerne forventes at forekomme - det er især her nye erfaringer og erkendelser skal sprogliggøres.

5. Metaforers funktioner skal i højere grad ses som nødvendige redskaber for at kunne tale om nye områder på en sammenhængende måde, i mindre grad som kognitive redskaber.

6. Generelt viser dette projekt, at det er en god ide at undersøge sproget empirisk og systematisk, før man udtaler sig om det.

\section{Referencer}

Deignan, Alice (1995). Collins Cobuild. English Guides 7: Metaphor. Glasgow: Harper Collins Publishers.

Lakoff, George og Mark Johnson (1999). Philosophy in the Flesh. The Embodied Mind and its Challenge to Western Thought. New York: Basic Books. 
